\title{
Water Quality of Hand-Dug Wells Close to Pit Latrines: Implications for Sanitation and Health.
}

\author{
${ }^{1}$ Olayinka, Olufunmilayo O. ${ }^{2}$ Adedeji, Oludare $\mathrm{H}^{*}$ and Sanni, S.S. \\ ${ }^{1,2}$ Department of Environmental Management and Toxicology Federal University of Agriculture, PMB 2240, \\ Abeokuta, Nigeria
}

\begin{abstract}
This study assessed impacts of pit latrines on water quality from hand-dug wells in Isara-Remo, Ogun State, Nigeria and its health implication. Water quality parameters: $\mathrm{pH}$, chloride, nitrate, ammonium, electrical conductivity, turbidity, total acidity and total alkalinity were determined using standard methods. Faecal coliform, Escherichia coli and Salmonella spp. were determined by standard methods. Total acidity ranged from $100 \mathrm{mg} / \mathrm{l}$ to $500 \mathrm{mg} / \mathrm{l}$, which was far above the WHO limit. Ammonium ranged from 0-2.50 mg/l, while nitrate concentration varied from 26.60 - $49.60 \mathrm{mg} / \mathrm{l}$, which were very close to the WHO limit of $50 \mathrm{mg} / \mathrm{l}$ for portable water. Distances between the pit latrines and the hand-dug wells were generally less than recommended $15 \mathrm{~m}$. Escherichia coli and Salmonella spp. were present in higher proportion (0.46x104 and $0.84 \times 104$ cfu/100ml respectively) which indicated that the wells were faecally contaminated. Epidemiological data revealed that the reported cases in clinics of water borne diseases like diarrhoea and typhoid fever were high, showing infections through consumption of contaminated water from the hang-dug wells. We advocate appropriate awareness and local institutional capacity building through provision of well-protected latrines, piped water and sustainable sanitation to reduce potential risk to public health.
\end{abstract}

Keywords: Bacteria, groundwater, pollution; sustainable development, urbanization

\section{Introduction}

Providing water and sanitation services to low-income communities is a key sustainable development challenge in urban areas especially in developing countries of the world ${ }^{[1-4]}$. In effort to promote sustainable sanitation and safe source of water, the World Health Organization had proposed an approach known as the water safety plan (WSP) as an effective means of consistently ensuring the safety of a drinking-water supply and encouraging sustainable development ${ }^{[5]}$. Sustainable sanitation refers to economically viable, socially acceptable sanitation solutions that protect human health without contributing to environmental degradation ${ }^{[6]}$. Concerning the safety of water, research evidences have shown that many low income countries are off-track to reach Target 7c of the Millennium Development Goals for water supply and sanitation, aimed at reducing by half the proportion of people without sustainable access to safe drinking-water and basic sanitation by $2015^{[7]}$. In spite of increasing international awareness of and attention to water and health, water, sanitation, and hygiene (WASH) challenges continue to plague the developing world ${ }^{[8]}$. Deficiency in sanitation is among the main causes of health problems among urban dwellers in African cities and is widely considered to contribute to poverty ${ }^{[9-11]}$. Although, the sanitation needs of the public have changed with a great majority having private access to toilets and washing facilities ${ }^{[12-13]}$; worldwide, about 2.6 billion people do not use improved sanitation, which is deffined as facilities that hygienically separate human excreta from human contact [14]. Several communities in Nigeria have witnessed remarkable economic and physical growth but in terms of improvement in the quality of the urban environment, they still lag behind developed countries. Many households like in other developing countries depend on rudimentary and poorly constructed or unimproved pit latrines ${ }^{[12,15]}$. In addition, almost one third of the population in Asian and African cities (both in urban and rural areas) use well water as a main source of drinking water ${ }^{[16]}$ (Subin and Aneesha, 2011), most of which are unprotected and sited close to pit latrines ${ }^{[17]}$. (Mulenga and McGranahan, 2011)

Pit latrine is widely used due to its low cost and availability ${ }^{[18-19]}$. Graham and Polizzotto ${ }^{[20]}$ observed that pit latrines are one of the most common human excreta disposal systems in low-income countries, and their use is on the rise as countries aim to meet the sanitation-related target of the Millennium Development Goals. Hand-dug wells are usually shallow, about $20 \mathrm{~m}$ or less and water from this source is used directly without treatment and could be faecally contaminated ${ }^{[21] \text { due }}$ to inadequacy of proper toilet facilities ${ }^{[22]}$. Most pit latrines were poorly constructed and lack physical barrier, such as concrete, between stored excreta and soil and/or groundwater ${ }^{23]}$ thus creating serious health risk ${ }^{[14]}$. Cairncross and Cliff $\left[{ }^{24]}\right.$ had earlier reported that soakage pits and pit latrines can extend their influence on groundwater quality up to $10 \mathrm{~m}$ or more as groundwater flow is either lateral or vertical. It is easy for excreta from the pit latrines to leach into nearby hand-dug wells, thereby threatening human health through well-water contamination ${ }^{[25-26]}$. It affects the physicochemical and bacteriological components of the water leading to infectious diseases. Inadequate sanitation, water supplies and 
poor hygiene are critical determinants for diarrhoeal diseases and infectious diseases transmitted by the faecaloral route ${ }^{[13]}$. Water-associated infectious diseases are a major cause of morbidity and mortality ${ }^{[27-28]}$, linked to unsafe water, sanitation and hygiene ${ }^{[29]}$. According to WaterAid ${ }^{[30]}$, around 4,000 people, mostly children, die every day as a result of diarrhoeal diseases; accounting for more than $40 \%$ of the total number of deaths related to unsafe water, inadequate sanitation facilities and poor hygiene behaviour. There is the need to ensure the safety of drinking-water supply using a comprehensive risk assessment and risk management approach ${ }^{\text {[31] }}$. However, Nigeria like other developing countries lacked adequate information on the levels of groundwater contamination from pit latrines ${ }^{[23]}$, which may hamper the achievement of sustainable sanitation and health. It is necessary to determine the extent of well water contamination in order to monitor likely danger to the public health.

This paper aimed to assess the effect of pit latrine on physico-chemical and bacteriological quality of water of nearby hand-dug well and its health implications in Isara, Remo North Local Government Area of Ogun State, SW, Nigeria. We hypothesized that the water quality of the wells were affected by faecal contaminant from nearby pit latrines.

\subsection{Study area}

\section{Materials and methods}

Isara is the sixth largest urban centre in Ogun state, Nigeria. It is the headquarters of the Remo North Local Government Area of the state. It is located between latitude $6^{\circ} 58^{\prime} 42^{\prime \prime}$ to $7^{\circ} 00^{\prime} 16^{\prime \prime} \mathrm{N}$ and longitude $3^{\circ}$ $41^{\prime} 03^{\prime \prime}$ to $3^{\circ} 41^{\prime} 14^{\prime \prime} \mathrm{E}$ (Figure 1). It is situated on a hilly topography of about 88 to $139 \mathrm{~m}$ above sea level. The geology is of the basement complex rock overlaid by the sedimentary rock of the Abeokuta formation whose lithology is sandstone ${ }^{[32]}$. The soil is generally sandy derived from the sandstone parent materials. Water table varies according to the topography, but is generally between 5 and 25 metres below the surface. Isara characterized by two mark seasons, the rain and dry seasons with mean annual rainfall ranging from $2032 \mathrm{~mm}$ to $2540 \mathrm{~mm}$. Until recently, the town is predominantly an agrarian settlement noted for kolanut, cocoa, cassava, cocoyam and other food crops. Like many other towns and cities in Nigeria, it lacks adequate basic infrastructures such as adequate water supply, poor sanitation and epileptic electric supply. Over $70 \%$ of the houses uses pit latrines, while only $20 \%$ have water closets and about $10 \%$ are without any form of toilet facilities, hence resort to open defecation (Personal Communication). Apart from few points with pipe-borne water, hand-dug well is the most common source of water supply.

\subsection{Sampling method}

The study was conducted in the wet season to determine the quality of the well water in close proximity to pit latrines. Three well water samples were taken from four different locations in the town namely: Aiyegbami, Sabo, Sokabi and Ijabata (Figure 1.0). The wells were labelled AW, SW, SBW and IW respectively, while the pit latrines close to them were labelled AT, ST, SBT and IT respectively. All water samples were taken directly from the well by means of approved sterilized bottle fitted with a weight at the base. Care was taken to avoid contaminating sample by any surface dirt. The water samples were de-chlorinated with sodium thiosulfate put in the collection bottles. Faecal coliform was run within 6 hours of samples collection, while E. coli was run within 24 hours of sample collection. This is because the time from sample collection to initiation of analysis may not exceed 30 hours ${ }^{[33]}$. Samples were kept at temperature below $10^{\circ} \mathrm{C}$ during transit. The distance of pit latrines, to hand dug wells were taken. Coordinates of the wells and pit latrines were recorded using hand-held GPS device. In the course of this investigation, the levels of faecal coliforms E. coli and Salmonella spp., ammonium, nitrate, conductivity, acidity, alkalinity, chloride, turbidity and $\mathrm{pH}$ were used as impact indicators.

\subsection{Physicochemical and bacteriological analysis}

Colour, odour, and smell of the well waters were determined by human sense of vision. The temperature was determined on field using thermometer. The $\mathrm{pH}$ was determined using $\mathrm{pH}$ meter. Total acidity, total alkalinity, chloride, nitrate, ammonium and conductivity were determined using standard methods ${ }^{[34]}$. Turbidity was measured using a HACH $2100 \mathrm{~N}$ turbidity kit. In order to maximize the comparability of results, bacterial microorganisms (faecal pollution and Escherichia coli (E. coli) were recovered and enumerated via culture-based most probable number (MPN) techniques in compliance with EPA guidelines ${ }^{[35]}$. 


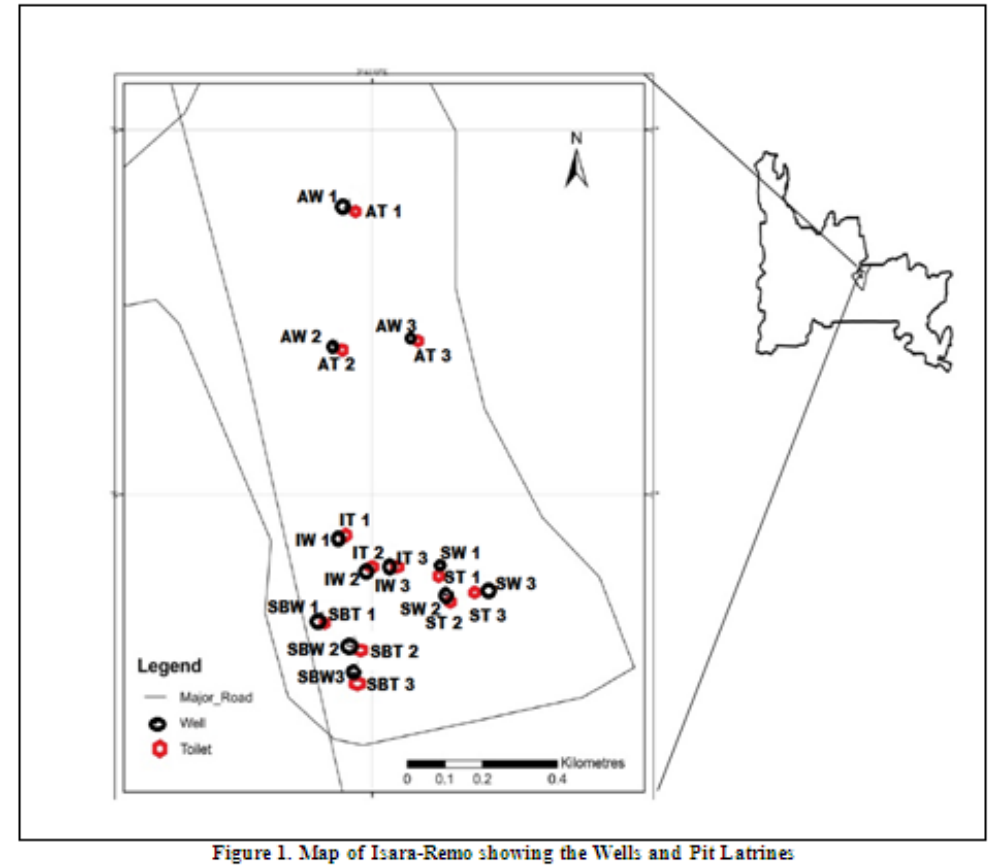

All analyses were performed by the membrane filtration technique with Millipore filters and equipment (Millipore Corp., Bedford, Mass.). Salmonella concentrations for well water samples were determined by the method described by Krometis et al. ${ }^{[36]}$. All samples were transported to the laboratory on ice to stop reproduction and bias that may occur at ambient temperature.

\subsection{Health data}

Prevalence of water- borne diseases in the study area was investigated by visiting the local government health centre and two private clinics in Isara -Remo where cases of water-borne diseases were documented. These were used to make preliminary inference of health impact of well water contamination by pit latrines. In the study area, the primary water sources were identified by speaking with the head of household and/or healthcare workers. The primary water source identified by majority of the people was hand dug wells. We considered the primary water sources and complaints of diarrhoea and other water related diseases in the health centre and private clinics.

\subsection{Data Analysis}

Data were analysed using both descriptive and inferential statistics. Correlation analysis was performed among the physico-chemical parameters of water from the hand-dug wells. For comparison of water quality parameters between wells, one-way ANOVA was used. Data were analysed using SPSS (Version 17).

\section{Results And Discussions}

3.1. Physico-chemical parameters

Physicochemical parameters of the selected wells were shown in Table 1. The result showed that the qualities of the well water were affected by bacterial from pit latrine. All the samples were colourless but some have offensive odour and sour taste. 
Water Quality of Hand-Dug Wells Close to Pit Latrines: Implications for Sanitation and Health.

Table 1. Physical and Chemical Properties of Well Water Samples.

\begin{tabular}{|c|c|c|c|c|c|c|c|c|c|c|}
\hline \multicolumn{2}{|c|}{ Locations } & \multirow{2}{*}{$\begin{array}{l}\begin{array}{l}\text { Temp } \\
\left({ }^{\circ} \mathbf{C}\right)\end{array} \\
27.20\end{array}$} & \multirow{2}{*}{$\begin{array}{l}\mathbf{p ~ H} \\
7.30\end{array}$} & \multirow{2}{*}{$\begin{array}{l}\begin{array}{l}\text { Chloride } \\
\text { Mg/L }\end{array} \\
28.60\end{array}$} & \multirow{2}{*}{$\begin{array}{l}\text { Nitrate } \\
\text { Mg/L } \\
26.60\end{array}$} & \multirow{2}{*}{$\begin{array}{l}\begin{array}{l}\text { Total } \\
\text { Acidity } \\
\text { Mg/L }\end{array} \\
200.00 \\
\end{array}$} & \multirow{2}{*}{$\begin{array}{l}\text { Total } \\
\text { Alkalinity } \\
\text { Mg/L } \\
84.00\end{array}$} & \multirow{2}{*}{$\begin{array}{l}\begin{array}{l}\mathrm{EC} \\
\boldsymbol{\mu} \mathrm{S} / \mathrm{cm})\end{array} \\
302.00\end{array}$} & \multirow{2}{*}{$\begin{array}{l}\text { Turbidity } \\
2.10\end{array}$} & \multirow{2}{*}{$\begin{array}{l}\text { A } \\
\text { Ammonium } \\
0.00\end{array}$} \\
\hline $\mathrm{A}_{1}$ & Aiyegbami & & & & & & & & & \\
\hline $\mathrm{A}_{2}$ & & 27.60 & 7.10 & 29.10 & 28.40 & 100.00 & 72.00 & 498.00 & 6.45 & 0.30 \\
\hline$A_{3}$ & & 29.60 & 7.50 & 40.20 & 32.80 & 350.00 & 105.00 & 476.85 & 8.45 & 0.00 \\
\hline$S_{1}$ & \multirow[t]{3}{*}{ Sabo } & 28.10 & 8.00 & 36.10 & 40.10 & 500.00 & 70.00 & 625.00 & 9.56 & 0.80 \\
\hline $\mathrm{S}_{2}$ & & 28.50 & 8.20 & 42.30 & 42.30 & 200.00 & 78.00 & 1152.50 & 10.20 & 2.50 \\
\hline $\mathrm{S}_{3}$ & & 29.20 & 8.10 & 47.40 & 34.50 & 200.00 & 89.00 & 761.00 & 3.45 & 0.15 \\
\hline $\mathrm{SB}_{1}$ & \multirow[t]{3}{*}{ Sokabi } & 27.90 & 7.70 & 27.80 & 43.10 & 500.00 & 104.00 & 906.20 & 8.75 & 0.80 \\
\hline$\overline{\mathrm{SB}_{2}}$ & & 28.00 & 7.20 & 38.80 & 28.10 & 300.00 & 101.00 & 598.00 & 12.34 & 0.15 \\
\hline $\mathrm{SB}_{3}$ & & 29.40 & 7.80 & 32.70 & 40.80 & 100.00 & 72.00 & 708.40 & 8.20 & 0.90 \\
\hline $\mathrm{I}_{1}$ & \multirow[t]{3}{*}{ Ijabata } & 26.90 & 7.40 & 49.20 & 27.80 & 400.00 & 84.00 & 124.70 & 3.25 & 0.25 \\
\hline $\mathrm{I}_{2}$ & & 27.10 & 7.10 & 46.40 & 37.20 & 350.00 & 86.00 & 1036.76 & 9.65 & 1.60 \\
\hline$I_{3}$ & & 30.00 & 7.30 & 44.20 & 49.60 & 150.00 & 103.00 & 453.60 & 8.25 & 0.00 \\
\hline \multicolumn{2}{|c|}{${ }^{\mathrm{a}}$ WHO Standard } & NA & $\begin{array}{l}6.5- \\
9.5\end{array}$ & 250 & 50 & NA & 400 & & & 1.5 \\
\hline
\end{tabular}

${ }^{\mathrm{a}} \mathrm{WHO}(2011 \mathrm{~b})$

${ }^{\mathrm{b}}$ WHO (2004)

The well water temperature varies from 26.9 to $30 \mathrm{oC}$. The $\mathrm{pH}$ of the samples ranged from 7.10-8.20 with mean of 7.60 while turbidity ranged from 2.10 - 12.30 NTU. Conductivity ranged from 124.70-1152.50 $\mu \mathrm{S} / \mathrm{cm}$ with a mean $\pm \mathrm{SD}$ of $636.9 \pm 189.9 \mu \mathrm{S} / \mathrm{cm}$ for all sampled wells. The nitrate concentration in the samples varied from $26.60-49.60 \mathrm{mg} / \mathrm{l}$ with mean $\pm \mathrm{SD}$ of $35.90 \pm 4.50 \mathrm{mg} / \mathrm{l}$. Ammonium values ranged from zero to $2.50 \mathrm{mg} / \mathrm{l}$ for the sampled wells. All the wells have relatively low chloride levels with a mean value of $38.64 \pm$ $6.86 \mathrm{mg} / \mathrm{l}$. The total titratable acidity ranged from $100.00-500.00 \mathrm{mg} / \mathrm{l}$ with the mean \pm SD of $279.20 \pm 41.67$ $\mathrm{mg} / \mathrm{l}$, while total alkalinity ranged from $72.0-105.00 \mathrm{mg} / \mathrm{l}$ with mean $\pm \mathrm{SD}$ of $87.33 \pm 6.0 \mathrm{mg} / \mathrm{l}$. Alkalinity Table 1 also showed the WHO permissible limits for selected water physico-chemical parameters. Distances between the pit latrines and hand dug wells varied from 10.2 to $16.4 \mathrm{~m}$ in the study area, which is less than the required 30 metres for ecological sanitation thus raising the risk of contamination of the water sources as coliforms could migrate from the pit latrines to the wells (Table 2).

Table 2 Distance of Pit Latrine to Hand Dug Wells.

\begin{tabular}{|l|l|}
\hline Wells & Distance of Pit to Wells M) \\
\hline $\mathrm{A}_{1}$ & 13.7 \\
\hline $\mathrm{A}_{2}$ & 14.2 \\
\hline $\mathrm{A}_{3}$ & 14.1 \\
\hline $\mathrm{S}_{1}$ & 14.4 \\
\hline $\mathrm{S}_{2}$ & 10.2 \\
\hline $\mathrm{S}_{3}$ & 13.1 \\
\hline $\mathrm{SB}_{1}$ & 15.2 \\
\hline $\mathrm{SB}_{2}$ & 16.4 \\
\hline $\mathrm{SB}_{3}$ & 15.8 \\
\hline $\mathrm{I}_{1}$ & 14.9 \\
\hline $\mathrm{I}_{2}$ & 15.4 \\
\hline $\mathrm{I}_{3}$ & 12.8 \\
\hline
\end{tabular}

\subsection{Bacteriological Composition}

In terms of microbial safety, enteric diseases have being reported to be the main public health concern associated with drinking water $\left[{ }^{37-38]}\right.$. The major indicators of microbial safety of drinking water include heterotrophic plate counts (HPC), total coliform (TC), faecal coliform (FC) and Escherichia coli (E. coli). However, according to Bartram et al ${ }^{[39]}$, it is impractical to look for all known enteric pathogens that may contaminate drinking water, hence microbial safety in this study were assessed through detection of indicators of faecal pollution, Escherichia coli (E. coli) and Salmonella spp. The results of the enumeration of faecal coliforms, E. coli and Salmonella spp. are shown in Figure 2. Faecal coliforms were present in a concentration ranging from $1.9 \times 104 \mathrm{CFU} / 100 \mathrm{ml}$ at AW2 to $4.25 \mathrm{X} 104 \mathrm{CFU} / 100 \mathrm{ml}$ at SW2. Concentration of E. coli was between $0.126 \mathrm{X} 104 \mathrm{CFU} / 100 \mathrm{ml}$ at SW1 to $0.64 \mathrm{X} 104 \mathrm{CFU} / 100 \mathrm{ml}$ at IW3 using the standard method of membrane filtration. Salmonella spp. was found to show a variation between zero at SW1 and SW2 to $1.0 \mathrm{X} 104$ $\mathrm{CFU} / 100 \mathrm{ml}$ at $\mathrm{AW} 1$. 


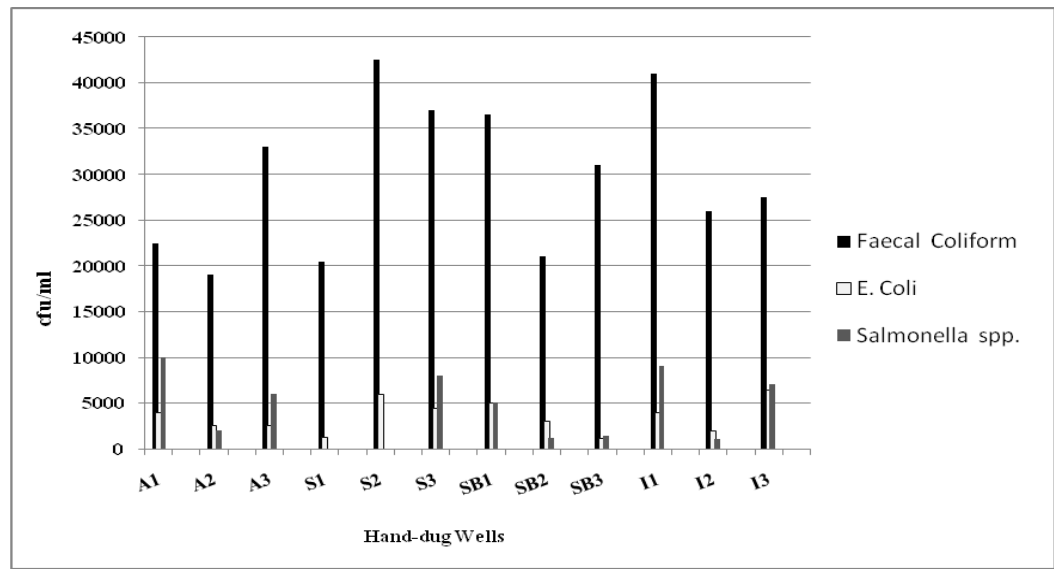

Figure 2. Bacteriological composition of water samples collected from hand-dug wells.

\subsection{Health Data}

Table 3 revealed that $80 \%$ of the health centre visited had at least 15 reported cases of typhoid fever among people below age 20 years. Diarrhoea and gastro-enteritis were more prevalent at age 10 and below than all other age groups.

Table 3. Prevalence of Water Borne Diseases in health centres and clinics

\begin{tabular}{|c|c|c|c|c|}
\hline \multicolumn{5}{|c|}{ Isara- Remo North Local Govt. Health Centre } \\
\hline S/No. & Age & Typhoid fever & Diarrhoea & Gastro-enteritis Fever \\
\hline 1 & $0-10$ & 68 & 144 & 24 \\
\hline 2 & $11-20$ & 53 & 3 & 2 \\
\hline 3 & $21-40$ & 118 & 26 & 13 \\
\hline 4 & $41-60$ & 59 & 10 & Nil \\
\hline 5 & 61 above & 13 & 5 & Nil \\
\hline & Total & 311 & 188 & 39 \\
\hline \multicolumn{5}{|c|}{ Anu Olu Polyclinic } \\
\hline 1 & $0-10$ & 35 & 92 & 18 \\
\hline 2 & $11-20$ & 40 & 10 & 6 \\
\hline 3 & $21-40$ & 62 & 11 & 5 \\
\hline 4 & $41-60$ & 22 & 4 & 3 \\
\hline 5 & 61 above & 10 & 2 & 3 \\
\hline & Total & 169 & 119 & 35 \\
\hline \multicolumn{5}{|c|}{ El-Shaddai Health Centre \& Maternity } \\
\hline 1 & $0-10$ & 18 & 41 & 9 \\
\hline 2 & $11-20$ & 15 & 17 & 4 \\
\hline 3 & $21-40$ & 21 & 7 & 5 \\
\hline 4 & $41-60$ & 9 & Nil & 5 \\
\hline 5 & 61 above & 4 & 4 & 3 \\
\hline & Total & 67 & 69 & 26 \\
\hline
\end{tabular}

There are significant correlations among measured water quality parameters such as $\mathrm{pH}$ and temperature (0.93), nitrate and conductivity (0.76), and conductivity and turbidity $(0.73)$ at $\mathrm{p}<0.05$ significant level (Table 4.0). The result of ANOVA analysis performed had the calculated $F$ value of 42.12, which confirms the significance of the regression equation (Table 5). It showed that pit latrines significantly affect the water in the hand-dug well close to them.

Table 4. Correlations among selected water quality parameters

\begin{tabular}{|c|c|c|c|c|c|c|c|c|c|}
\hline & Temp & $\mathrm{pH}$ & $\mathrm{Cl}$ & Nitrate & $\begin{array}{c}\text { Total } \\
\text { Acidity }\end{array}$ & $\begin{array}{c}\text { Total } \\
\text { Alkalinity }\end{array}$ & $\mathrm{EC}$ & Turbidity & $\mathrm{NH} 4$ \\
\hline Temp & 1.00 & & & & & & & & \\
\hline $\mathrm{pH}$ & 0.93 & 1.00 & & & & & & & \\
\hline $\mathrm{Cl}$ & -0.20 & 0.12 & 1.00 & & & & & & \\
\hline Nitrate & 0.41 & 0.52 & 0.65 & 1.00 & & & & & \\
\hline Total Acidity & 0.39 & 0.45 & 0.58 & 0.99 & 1.00 & & & & \\
\hline Total Alkalinity & -0.58 & -0.79 & -0.20 & -0.10 & 0.04 & 1.00 & & & \\
\hline $\mathrm{EC}$ & 0.90 & 0.90 & 0.16 & 0.76 & 0.74 & -0.45 & 1.00 & & \\
\hline Turbidity & 0.58 & 0.38 & -0.12 & 0.66 & 0.74 & 0.27 & 0.73 & 1.00 & \\
\hline $\mathrm{NH} 4$ & 0.70 & 0.85 & 0.55 & 0.87 & 0.81 & -0.55 & 0.90 & 0.49 & 1.00 \\
\hline
\end{tabular}

Note: $* *$ Significance at $\mathrm{p}<0.05$ 
Water Quality of Hand-Dug Wells Close to Pit Latrines: Implications for Sanitation and Health.

Table 5. Analysis of Variance

\begin{tabular}{lrrrrrr}
\hline \multicolumn{1}{c}{ Source of Variation } & \multicolumn{1}{c}{ SS } & \multicolumn{1}{c}{ df } & \multicolumn{1}{c}{ MS } & F & P-value & F crit \\
\hline Between Groups & 1420216.21 & 8.00 & 177527.03 & 42.12 & 0.00 & 2.31 \\
Within Groups & 113799.91 & 27.00 & 4214.81 & & & \\
Total & 1534016.12 & 35.00 & & & & \\
\hline
\end{tabular}

\subsection{Physico-chemical properties of well water}

This study examined the effect of pit latrine on physico-chemical and bacteriological quality of water from nearby hand-dug well and its health implications in Isara, Remo North Local Government Area of Ogun State, SW, Nigeria. A critical examination of water samples from hand-dug wells showed significant impaction due to proximity to the pit latrines. This affected physico-chemical properties of the water. Temperature varies from 26.9 to $30.0 \mathrm{oC}$, which is significant to the total coliforms and E. coli in water bodies ${ }^{[40]}$. Water $\mathrm{pH}$ ranged from 7.10-8.20 with mean of 7.60 and this within the portable water standards ${ }^{[21]}$. However, pathogens can thrive at $\mathrm{pH} \geq 5.0$ thus making the water potentially hazardous to health ${ }^{[41]}$. Another implication of the low $\mathrm{pH}$ may include corrosion, solubility of heavy metals and impartation of bitter and metallic taste in water ${ }^{[42-43]}$. Total acidity ranged from $100 \mathrm{mg} / \mathrm{l}$ to $500 \mathrm{mg} / \mathrm{l}$, which was far above the limit recommended by World Health Organization ${ }^{[44]}$, while total alkalinity that ranged from 70.00 to $104 \mathrm{mg} / \mathrm{l}$ were below the WHO $400 \mathrm{mg} / \mathrm{l}$ limit. Turbidity was high and ranges from 2.10 NTU to 12.34 NTU. High turbidity in some of these wells could be because of soil disturbance and resuspension within the well during water withdrawal. High turbidity can stimulate bacteria growth, which indicates problems with treatment processes ${ }^{[45]}$. Conductivity ranged from $124.70 \mu \mathrm{S} / \mathrm{cm}$ in a well at Ijabata to $1152.50 \mu \mathrm{S} / \mathrm{cm}$ in SW2 at Sabo area. Conductivity at Ijabata is above the WHO desirable limit for EC in drinking water of $1000 \mu \mathrm{S} / \mathrm{cm}^{[45]}$. Conductivity is a measure of dissolved ions and their behaviour is similar to that of ammonium, and nitrate ions ${ }^{[34]}$. One of the wells (SW2) in Sabo area has ammonium concentration of $2.50 \mathrm{mg} / \mathrm{l}$, which is above the WHO permissible limit of $1.5 \mathrm{mg} / \mathrm{l}^{[45]}$. This could possibly explain the high conductivity of the well water. Nitrate concentration varied from $26.60-49.60$ $\mathrm{mg} / \mathrm{l}$, which were high and very close to the WHO permissible limit of $50 \mathrm{mg} / \mathrm{l}$ for portable water ${ }^{[45]}$. The preferred level of nitrogen in groundwater is less than $10 \mathrm{mg} / \mathrm{l}$, but sustained levels of over $20 \mathrm{mg} / \mathrm{litre}$ are required before any significant health risk is posed ${ }^{[46]}$. Nitrate form nitrosamine in the stomach, which causes gastric cancer ${ }^{[47]}$. High levels of nitrate-nitrogen are directly associated with methaemoglobinaemia, or blue baby syndrome, an acute condition common among bottle-fed infants of less than three months of age ${ }^{[48]}$. Human and animal sewage are major sources of nitrate in groundwater ${ }^{[49]}$. The mean concentration of 38.64 $\mathrm{mg} / \mathrm{l}$ recorded for chloride was far below the permissible limit of $250 \mathrm{mg} / \mathrm{l}$ for portable water ${ }^{[44]}$. The chemical analysis suggest that the main factors influencing the nitrate, ammonia, and chloride values in the well water are the proximity of the wells to pit latrines and the sandy nature of the soil.

\subsection{Bacteriological contamination}

The results of the bacteriological analyses reveal contamination of the well water by faecal matter from the pit latrines. Generally, the extent to which bacteria or pathogens from pit latrine wastes may be transported and contaminate groundwater largely depends on the environmental context of the area, particularly climatic, hydrological and soil conditions ${ }^{[20,26]}$. In this study faecal coliforms in the well water ranged from $1.9 \times 104$ CFU/100 ml at AW2 to $4.25 \mathrm{X} 104 \mathrm{CFU} / 100 \mathrm{ml}$ at SW2), while E. coli was between $0.126 \mathrm{X} 104 \mathrm{CFU} / 100 \mathrm{ml}$ at SW1 to $0.64 \mathrm{X} 104 \mathrm{CFU} / 100 \mathrm{ml}$ at IW3 (Figure 2). Salmonella spp. often associated with diarrhoea and gastoentrisis was detected in all the wells except Sabo 1 (S1) and Sabo 2 (S2). It ranged from zero 1.4 X 104 $\mathrm{CFU} / \mathrm{ml}$. The presence of indicator organisms (E. coli) in water indicates contamination of the water source with faecal matter and hence possible presence of intestinal pathogens ${ }^{[50]}$ or what Robertson ${ }^{[51]}$ referred to as microbiological failures. Of the indicators described here, E. coli is the only microbial indicator associated with public health significance ${ }^{[52]}$. It is the most reliable indicator of enteric diseases and is therefore the indicator of choice to indicate occurrence of recent faecal contamination in drinking water systems ${ }^{[53]}$. It is worth noting that a positive result for E. coli is not necessarily a measure of waterborne pathogen occurrence ${ }^{[42]}$, neither does nondetection nor a negative E. coli result guarantee that water is safe to drink $\left[{ }^{54]}\right.$. Coliforms detected in well water may have migrated from faecal matter in the pit latrines through the soil to the water sources due to the very short distance between the pit latrines and the wells ${ }^{[9]}$. Distances between the pit latrines and hand-dug wells (Table 3) varied from 10.2 to $16.4 \mathrm{~m}$, which raises the risk of contamination of the water sources as coliforms could leach from the pit latrines into nearby wells. Furthermore, Vinger et al. ${ }^{[55]}$ suggested that wells are likely to be contaminated if pit latrines are $<12 \mathrm{~m}$ away. Although Dzwairo et al. ${ }^{[48]}$ found faecal and total coliform contamination greatly reduced at $>5 \mathrm{~m}$ from pit latrines, a distance of $30 \mathrm{~m}$ is however required for ecological sanitation. 


\subsection{Health Implications}

The study revealed high faecal contamination in the well water in Isara, which shows high possibility of the presence of disease pathogens. There are many cases of water-related diseases and infections reported in the health centre and private clinic visited during the study showing many people drank from contaminated water sources. E. coli O157:H7 a strains of E. coli bacteria have being identified to cause illness, such as hemorrhagic diarrhoea and haemolytic uremic syndrome HUS) which causes kidney failure, which could jeopardize the health of young children and anyone with a challenged immune system ${ }^{[56-58] .}$ In this study, diarrhoea and gastro-enteritis were more prevalent among children of school age 10 while many adults are down with typhoid fever. This has potential direct and indirect public health and economic impacts. Water-related diseases often affect peoples' productivity as illnesses related to poor sanitation have direct impact on household finances in terms of the financial expenditure to pay for medicines and primary healthcare as well as the loss of working days due to sickness ${ }^{[13]}$. Hygiene promotion is widely acknowledged as one of the most cost-effective public health interventions ${ }^{[10,59]}$. Therefore, it is essential that public health professionals work collaboratively to identify access and manage public health risks, and take action to communicate these risks effectively to all affected parties ${ }^{[00]}$.

\section{Conclusions}

It is evident that most hand-dug wells in the study area were contaminated with faecal matter that leached from nearby pit latrines, which has negative implication to achieving sustainable health. The hand-dug well water quality fell short of the WHO guidelines for drinking water quality and improved urban sanitation, promotion of hygienic behaviour can help reduce the risk of exposure to pathogens, and hazardous substances that could affect public health at all points of the sanitation system; and eventually contribute to the socioeconomic development. There is the urgent need for the promotion of the delivery of sustainable water supply, sanitation and hygiene (WASH) services by improving the water quality at the source through adequate protection of well water, treatment and provision of alternative sources such as improved pipe-borne water to the people. Sitting wells at higher elevations of at least 30 metres and the bottom of the pits should be at least 1.5 metres above the groundwater table.

\section{References}

[1]. O K, Adeyemo, O A. Banwo and E A. Adeleye, Regression Based Modelling of Relationship Between Lead in Water and Lead Bioaccumulation in Fish. Global Journal of Environmental Research 1(3), (2007).117-123.

[2]. C. Lüthi, A. Panesar, T. Schütze, A. Norström, J. McConville, J. Parkinson, D. Saywell, R. Ingle Sustainable Sanitation in Cities- A Framework for Action. Sustainable Sanitation Alliance (SuSanA) \& International Forum on Urbanism (IFoU), Papiroz Publishing House, The Netherlands. 2011. Available at www.papiroz.com (Accessed 16 $6^{\text {th }}$ October 2013).

[3]. C. Govindasamy and M. Subdaramoorthy, Impact of Municipal Waste on the Water Quality of River Palar, Tamilnadu, India. Global Journal of Environmental Research, 5, 2011.39-45.

[4]. K. Claes, L. Vandenbussche, A. Versele, R. Klein and B. Verbist, Sustainable urban planning and construction in the South. KLIMOS Working paper 7, KLIMOS, Leuven, Belgium. 2012

[5]. A. Cotton, J. Adams and D. Shaw, Improving water supply and sanitation programme effectiveness: lessons from WaterAid's outcome evaluation studies. Water and Environment Journal, 27, 2013, 1-9

[6]. SIDA Water and Sanitation. Information Brief No.6 August 2012. Available at: sida@sida.se

[7]. World Health Organization (WHO). Progress on Sanitation and Drinking Water. 2011a. Available online http://www.wssinfo.org/fileadmin/user_upload/resources/1278061137JMP_report_2010en.pdf. (Accessed June 12 2013)

[8]. M. Palaniappan, M. Lang and P.H. Gleick, A Review of Decision-Making Support Tools in the Water, Sanitation, and Hygiene Sector. Woodrow Wilson International Center for Scholars, Spring 2008

[9]. E.W. Kimani-Murage and A.M. Ngindu, Quality of Water the Slum Dwellers Use: The Case of a Kenyan Slum. Journal of Urban Health: Bulletin of the New York Academy of Medicine, 84(6), 2007, 829-839

[10]. O. Gautam, B. Adhikari, K. Rajbhandari and O. Jones, Stages of hygiene monitoring: An operational experience from Nepal. South Asia Hygiene Practitioners' Workshop. Dhaka, Bangladesh, February 2010 pp. 1-12

[11]. J.T. Tukahirwa, A.P.J. Mol, and P. Oosterveer, Access of urban poor to NGO/CBO supplied sanitation and solid waste services in Uganda: The role of social and spatial proximity Habitat International, 35, 2011, 582-591.

[12]. P.M. McDermott and W.G. Kernohan, The adequacy and public perception of the public toilet provision on Guernsey. Journal of Environmental Health Research, 12(1), 2013. 59-67

[13]. A, Norström, C. Lüthi and J. McConville State of Urban Sanitation. Chapter 2. In: C. Lüthi, A. Panesar, T. Schütze, A. Norström, J. McConville, J. Parkinson, D. Saywell, R. Ingle. Sustainable Sanitation in Cities - A Framework for Action. Sustainable Sanitation Alliance (SuSanA) \& International Forum on Urbanism (IFoU), Papiroz Publishing House, the Netherlands. $2011 . \quad$ Available at www.papiroz.com (Accessed $16^{\text {th }}$ October 2013).

[14]. A. Hendriksen, J. Tukahirwa, P.J.M. Oosterveer and A.P.J. Mol, Participatory Decision Making for Sanitation Improvements in Unplanned Urban Settlements in East Africa. Journal of Environment \& Development. 21(1), 2012, 98-119

[15]. JMP, Progress on Sanitation and Drinking Water: 2010 Update. WHO/UNICEF Joint Monitoring Programme (JMP) for Water Supply and Sanitation, WHO, Geneva, Switzerland. 2010.

[16]. M.P. Subin and V.A. Aneesha. An evaluation of physico-chemical properties to assess well water quality in some areas of Ernakulam district, Kerala, India Nature Environment and Pollution Technology, 10(3), 2011,409-413

[17]. M. Mulenga and G. McGranahan Urban wells: a vital but ignored resource. IIED Reflect \& act, IIED Human Settlements Group. July, 2011. 
[18]. N. Jain, Getting Africa to Meet the Sanitation MDG: Lessons from Rwanda. Washington, DC: World Bank Water and Sanitation Program. 2011. Available: http://www.wsp.org/sites/wsp.org/files/publications/wsp-rwanda-sanitation-lessons.pdf (Accessed 16 ${ }^{\text {th }}$ October 2013).

[19]. P.N. Bao, T. Aramaki, and K. Hanaki, Assessment of stakeholders' preferences towards sustainable sanitation scenarios. Water and Environment Journal, 271, 2013, 58-70

[20]. J.P. Graham and M.L. Polizzotto, Pit Latrines and Their Impacts on Groundwater Quality: A Systematic Review. Environ Health Perspect 121, 2013, 521-530 http://dx.doi.org/10.1289/ehp.1206028 (Accessed $16^{\text {th }}$ October 2013)

[21]. World Health Organization (WHO) Guidelines for drinking water quality. Recommendations, Vol. 1, Second Ed. World Health Organisation, Geneva, Switzerland. 1993.

[22]. M. Pritchard, T.O. Mkandaware and J.G. Nalli, Biological, Chemical and Physical drinking water quality from shallow well in Malawi; Case study of Blantyre. Chira and Malanje. 2007.

[23]. F. Almansi, A. Hardoy and J. Hardoy, Improving water and sanitation provision in Buenos Aires. What can a research-oriented NGO do? Human Settlements Working Paper Series. Water, 22. June 2010.

[24]. S. Cairncross and J.L. Cliff, Water use and health in Mireda, Mozambique. Trans. Royal Soc. Trop. Med. Hyg. 81, 1987, 51-54

[25]. G. Howard and T. Boonyakarnkul, Sanitary completion of protection works around groundwater sources. Chapter 18. In: World Health Organization. Protecting Groundwater for Health: Managing the Quality of Drinking-water Sources. Eds., Schmoll, O. G. Howard, J. Chilton, I. Chorus, Published by IWA Publishing, London, UK. 2006.

[26]. G. Banerjee Underground pollution travel from leach pits of on-site sanitation facilities: a case study. Clean Technol. Environ Policy 13(3), 2011, 489-497.

[27]. S. Lewin, R. Norman, N. Nannan, E. Thomas and D. Bradshaw, Estimating the burden of disease attributable to unsafe water and lack of sanitation and hygiene in South Africa in 2000. S Afr. Med J, 97, 2007, 755-762.

[28]. K. Yang, J. LeJeune, D. Alsdorf, B. Lu and C.K. Shum et al. Global Distribution of Outbreaks of Water-Associated Infectious Diseases', PLoS Neglected Tropical Diseases 62: 2012, e1483. doi:10.1371/journal.pntd.0001483.

[29]. P.D. Hynds, B.D. Misstear, and L.W. Gill, Development of a microbial contamination $\quad$ susceptibility model for private domestic groundwater sources. Water Resources Research, 4812, 2012.W12504.

[30]. WaterAid, Fatal Neglect - How Health Systems are Failing to Comprehensively Address Child Mortality. London, UK. 2009.

[31]. A. Hazra, Challenges in setting up a potable water supply system in a United Nations peacekeeping mission: The South Sudan experience. International Journal of Hygiene and Environmental Health 216, 2013, 88-90

[32]. O. Kehinde-Phillips, Geology of Ogun State. In: Ogun State in Maps. Eds. Onakomaiya et al., Department of Geography and Regional Planning, Ago-Iwoye, Nigeria. Rex Charles Publication. Ibadan, Nigeria. 1992. Pp 12-13

[33]. EPA, Standard Methods for the Examination of Water and Wastewater, 21st Edition 2005

[34]. APHA, Standard Methods for the Examination of Water and Wastewater, 20 edn. American Public Health Association, Washington, DC. 1998.

[35]. EPA Analytical Methods Approved for Drinking Water Compliance Monitoring under the Total Coliform Rule. http://www.standardmethods.org/ 2009.

[36]. L.H. Krometis, G.W. Characklis, P. N. Drummey and M.D. Sobsey. Comparison of the presence and partitioning behaviour of indicator organisms and Salmonella spp. in an urban watershed. Journal of Water and Health 8(1), 2010, 44-59

[37]. P. Payment, M. Waite and A. Dufour, Introducing parameters for the assessment of drinking water quality. London, UK: IWA Publishing. 2003.

[38]. U.S. Environmental Protection Agency (USEPA). Distribution system indicators of drinking water quality. Washington, DC: EPA; $2006 \mathrm{Dec}$. http://www.epa.gov/ogwdw/disinfection/tcr/pdfs/issuepaper_ter_indicators.pdf

[39]. J. Bartram, J. Cotruvo, M. Exner, C. Fricker and A. Glasmacher (Eds.) Heterotrophic counts and drinking-water safety: the significance of HPCs for water quality and human health. London, UK: IWA Publishing. 2003.http://www.who.int/water_sanitation_health/dwq/hpc/en/index.html

[40]. A.A. Olajire and F.E. Imeokporia Water quality assessment of Osun River studies in inorganic nutrients. Environ. Monitoring Asses, 69, 2001, 17-23

[41]. Y. Beteseb, B. Mulugeta and A. Mogessie, Fate of Salmonella species and E. coli in Fresh-Prepared Orange, Avocado, Papaya and Pine Apple Juices. Ethiop J Health Sci. 11(2), 2001, 89-95

[42]. U.S. Environmental Protection Agency (USEPA) (2010). Proposed revised total coliform rule; assessments and corrective actions guidance manual. Washington, DC: U.S. EPA Office of Ground Water and Drinking Water; Standards and Risk Management Division; Aug 2010. http://water.epa.gov/lawsregs/rulesregs/sdwa/tcr/regulation.cfm

[43]. A.M. Gbadebo, A.M Taiwo, H. Ayedun, and A.J. Adeola. Geochemical Analysis of Groundwater Qualityiln Agbara and Environs. Applied Ecology and Environmental Research 10(3), 2012, 375-384. http://www.ecology.uni-corvinus.hu

[44]. World Health Organization (WHO) (2011b). Guidelines for Drinking-water Quality. 4th ed. Geneva: WHO. Available: http://whqlibdoc.who.int/publications/2011/9789241548151_eng.pdf (Accessed June 12 2013).

[45]. World Health Organization (WHO) Guidelines for Drinking-Water Quality, Vol. 1, Third Ed. World Health Organisation, Geneva, Switzerland. 2004.

[46]. D.A. Still and S.R. Nash Groundwater contamination due to pit latrines located in a sandy aquifer: a case study from Maputaland. In: Water Institute of Southern Africa Biennial Conference. Durban, South Africa: Water Institute of Southern Africa, 1-6, 2002. Available:

http://www.sswm.info/sites/default/files/reference attachments/STILL\%20and\%20NAH\%202002\%20Groundwater\%20contaminat ion\%2due\%20to\%20pit\%20latrines\%20located\%20i $\quad$ n\%20a\%20sandy\%20aquifer.pdf (Accessed $16^{\text {th }}$ October 2013)

[47]. A. Durrani, Physico-Chemical Parameters of Groundwater. African Journal of Basic \& Applied Sciences 4 (2), 2012, 28-29

[48]. B. Dzwairo, Z. Hoko, D. Love and E. Guzha, Assessment of the impacts of pit latrines on groundwater quality in rural areas: A case study from Marondera district, Zimbabwe. Physics and Chemistry of the Earth 31, 2006, 779-788

[49]. M.O. Eduvie and I.O. Olaniyan, Groundwater Quality Appraisal in Southern Parts of Kaduna State, Nigeria. American Journal of Environmental Engineering, 31, 2013, 77-83. Doi: 10.5923/j.ajee.20130301.11

[50]. G. Wilkes, et al., Associations among pathogenic bacteria, parasites, and environmental and land-use factors in multiple mixed-use watersheds' Water Resources, 45, 2011, 5807-5825.

[51]. S.J. Robertson, Disinfection observations on a major \pm unfiltered water supply in Scotland, Water and Environment Journal, 27, 2012, 127-137

[52]. S. Verhille, Understanding microbial indicators for drinking water assessment: interpretation of test results and public health significance. National Collaborating Centre for Environmental Health. 2013. 
[53]. P. Tallon, B. Magajna, C. Lofranco and K.T. Leung, Microbial indicators of faecal contamination in water: a current perspective. Water Air Soil Pollut. 166, 2005, 139-66

[54]. M.J. Allen, S.C. Edberg, J. Clancy and S.E. Hrudey, Drinking water microbial myths - a primer for utility managers, engineers and non-microbiologists. 15th National Conference \& 6th Policy Forum on Drinking Water. Kelowna, B. C. 2012.

[55]. B. Vinger, M. Hlophe and M. Selvaratnam, Relationship between nitrogenous pollution of borehole waters and distances separating them from pit latrines and fertilized fields. Life Sci. J., 9(1), 2012, 402-407.

[56]. S.J. Olsen, G. Miller, T. Breuer, M. Kennedy, C. Higgins and J. Walford et al. A Waterborne Outbreak of Escherichia coli O157:H7 Infections and Hemolytic Uremic Syndrome: Implications for Rural Water Systems. Emerging Infectious Diseases, 84, 2002, 370-375.

[57]. H. Karch, P. Tarr and M. Bielaszewska Enterohaemorrhagic Escherichia coli in human medicine. Int. J Med Microbiol, 295 (6-7), 2005, 405-18.

[58]. R.I. McDonald, I. Douglas, C. Revenga, R. Hale, N. Grimm, J. Grönwall and B. Fekete, Global urban growth and the geography of water availability, quality, and delivery. Ambio, 40, 2011. 437-446.

[59]. R.L. Atenstaedt, H. Brunt, S.B. Cottrill, C.D. Johnson, and C. Whiteside, Good practice $\quad$ in risk communication: A case study related to people residing on an infilled clay pit. Journal of Environmental Health Research 10(1), 2010, 55-63

[60]. E.A. Zilov, Water resources and the sustainable development of humankind: International cooperation in the rational use of freshwater-lake resources: Conclusions from materials of foreign studies. Water Resources, 40(1), 2013, 84-95. 